\title{
Water quality monitoring of an international wetland at Harike, Punjab and its impact on biological systems
}

\author{
Jasmit Kaur $^{1} \cdot$ Harpreet Walia $^{1} \cdot$ Samson Okongo Mabwoga $^{1} \cdot$ Saroj Arora $^{1}$
}

Received: 8 March 2013/Accepted: 1 October 2015/Published online: 17 October 2015

(c) The Author(s) 2015. This article is published with open access at Springerlink.com

\begin{abstract}
The present study entails the investigation of mutagenic and genotoxic effect of surface water samples collected from 13 different sites of the Harike wetland using the histidine reversion point mutation assay in Salmonella typhimurium (TA98) strain and plasmid nicking assay using $p B R 322$, respectively. The physicochemical characterization of water samples using different parameters was conducted for water quality monitoring. Heavy metal analysis was performed to quantify the toxic components present in water samples. It was observed that although the water samples of all the sites demonstrated mutagenic as well as genotoxic activity, the effect was quite significant with the water samples from sites containing water from river Satluj, i.e., site 1 (upstream Satluj river), site 2 (Satluj river) and site 3 (reservoir Satluj). The high level of pollution due to industrial effluents and agricultural run-off at these sites may engender the genotoxicity and mutagenicity of water samples.
\end{abstract}

Keywords Harike - Ramsar - Ames - Plasmid nicking · Monitoring

\section{Introduction}

Rivers, lakes and wetlands are major sources of potable water in the country. Contamination of these water resources with harmful chemicals is occurring at an alarming rate in India during the past few decades (Alam et al. 2009, 2010).

Saroj Arora

sarojarora.gndu@gmail.com

1 Department of Botanical and Environmental Sciences, Guru Nanak Dev University, Amritsar, Punjab 143005, India
Massive industrialization, urbanization, excessive utilization of pesticides in agriculture is the reason that threatens aquatic ecosystem and human beings (White and Rasmussen 1998). Punjab is mainly dependent upon surface water systems (i.e., rivers and wetlands) for water resources. Surface water system is used as source of drinking as well as agricultural, recreational and religious purposes. Wetlands are subjected to multiple environmental pressures such as water abstraction, industrial and domestic effluents, agricultural run-off, altered hydrology, habitat degradation and overexploitation of the resources. Surface water quality of the state is largely influenced by both natural as well as anthropogenic inputs resulting from industrial and domestic wastewater, as well as agricultural sources. The surface water quality is one of the important factors that directly concern the health of humans and aquatic organisms. The higher incidence of cancer and other health effects in the state can be related to the toxic components present in the water (Mathur et al. 2005). These toxic components can cause DNA damage, thus they are mutagenic in nature. Genotoxic testing of complex industrial effluents has demonstrated the presence of many unidentified and unregulated toxicants that are potential carcinogens. This has raised concern associated with their release into the water bodies (Houk 1992; Claxton et al. 1998; Tabrez and Ahmad 2011). The standard chemical analysis of the water samples can rarely provide an adequate assessment of the genotoxicity potential of complex mixture present in surface water (Ohe et al. 2004). However, bioassays can effectively assess the genotoxicity of complex mixtures without the requirement of prior information about their chemical composition. There are number of reports suggesting the correlation between pollution level and mutagenicity (Hubert et al. 2012). A number of animal, bacterial and plant-based assays have been developed for the estimation of mutagenic and genotoxic potential of water samples (Vargas et al. 1995; 
Tabrez and Ahmad 2011). The in vivo toxicity analysis using small mammals is a very long and expensive procedure, hence some in vitro analysis for routine evaluation of genotoxicity of water has been recommended. Among them, Ames test takes a prominent position, which detects the induced mutations in bacteria culture (Maron and Ames 1983; Ames 1984). On the other hand, amongst in vitro tests that evaluate the DNA damage, the plasmid nicking assay has been widely used and provides a valid indicator of genotoxicity (Mortelmans and Zeiger 2000). Therefore, this study was conducted to gain insight into the mutagenicity and genotoxicity of water samples by Ames and plasmid nicking assay, respectively, along with the physicochemical and heavy metal analysis for water quality assessment.

\section{Materials and methods}

\section{Chemical and reagents}

Salmonella typhimurium TA 98 strain was obtained from IMTC (Institute of Microbial Technology, Chandigarh). $p B R 322$ plasmid DNA was obtained from $\mathrm{GeNe}^{\mathrm{TM}}$. All other chemicals used were of analytical grade.

\section{Study area}

Harike wetland is the largest freshwater wetland of the country, covering an area of about 8435 ha (Fig. 1). It is an internationally recognized site falling into four districts viz. Amritsar, Firozpur, Kapurthala and Jalandhar in Punjab, India, between the latitudes $31^{\circ} 06^{\prime} \mathrm{N}$ and $31^{\circ} 12^{\prime} \mathrm{N}$ and longitudes $74^{\circ} 55^{\prime} \mathrm{E}$ and $75^{\circ} 05^{\prime} \mathrm{E}$. It is about $12 \mathrm{~km}$ long and $11 \mathrm{~km}$ in width (Mabwoga et al. 2010). The wetland came into existence in 1952 due to the formation of barrage at the confluence of river Sutlej and Beas at Harike Pattan, with the aim of storing and providing irrigation and drinking water to parts of southern Punjab, and to the adjoining state Rajasthan. The wetland is having high ecological value as it supports rare, vulnerable and endangered floral and faunal species and attracts large populations of avifauna during the winters. The wetland was declared as wildlife sanctuary in 1982 and in 1990; it was designated as Ramsar site and included in the list of Wetlands of International Importance under the Ramsar Convention (Ramsar Convention Secretariat 2006; Anonymous 2008). In 2000, the Sanctuary came under "Wild Life Act" and fishing was totally banned.

Over the years, wetland has been facing a threat from a developing economy with increasing pressure on the resources (Chopra et al. 2001; Jain et al. 2008). The wetland is getting degraded due to intense siltation, weed invasion, agricultural run-off and pollution brought in by river Sutlej and Beas (via Buddha Nullah, Chitti Bein, Kala Sanghian drain and Kali Bein (Dhillon et al. 1996; Ladhar 2002; Kaur et al. 1999). The impact of the polluted water is spread to a wide area of southern Punjab and Rajasthan, through the Harike waterworks.

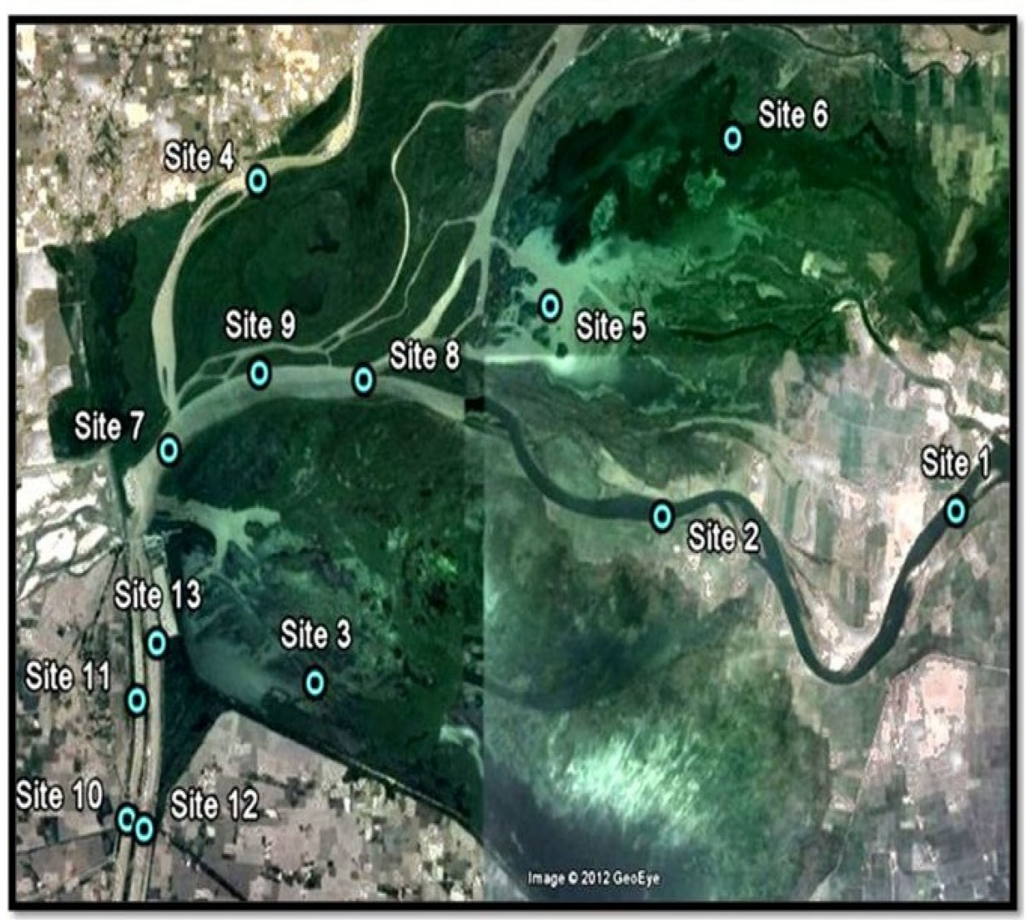

Fig. 1 Map of Harike wetland showing sampling area

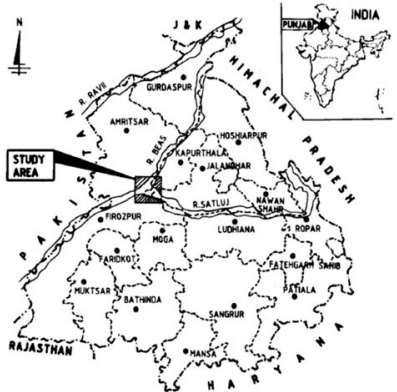

Site 1- Upstream River Satluj

Site 2- Satluj River

Site 3-Reservoir Satluj

Site 4- Upstream River Beas

Site5-Beas River

Site 6- Reservoir Beas

Site 7-Confluence point 1

Site 8-Confluence point 2

Site 9 - Confluence point 3

Site 10- Downstream Firozpur feeder

Site 11- Firozpur Feeder

Site 12- Downstream Rajasthan feedes

Site 13- Rajasthan feeder. 


\section{Water sampling}

Harike wetland is divided into two major parts, i.e., wetland area and feeder area. Wetland area comprises two rivers, i.e., Satluj and Beas, reservoirs for both the rivers, i.e., Reservoir Satluj (contains maximum water from river Satluj) and Reservoir Beas (contains maximum water from river Beas), and confluence point of both the rivers. Feeder area comprises two feeders called Rajasthan feeder and Firozpur feeder which supply water to Rajasthan and southern part of Punjab. To cover all the wetland and feeder areas, 13 sites of Harike wetland were fixed as shown in Fig. 1. Sampling sites in terms of latitude/longitude were determined using Global Positioning System (GPS). Garb sampling was carried out before Monsoon to eliminate the potential effect of rainfall. Samples were collected in sterile glass bottles, $20 \mathrm{~cm}$ below the surface of water as prescribed in the standard methods (APHA 1998). Samples were tested for the mutagenicity and DNA damaging assay as soon as possible. Prior to the mutagenicity assay, test samples were filter sterilized by passing through $0.22 \mu \mathrm{m}$ filters to remove turbidity. For chemical analysis, samples were processed according to the methods described in APHA. Samples were stored in deep freezer at $4{ }^{\circ} \mathrm{C}$ until used.

\section{Ames assay}

The $S$. typhimurium mutagenicity assay given by Maron and Ames (1983) was performed on filter-sterilized water samples using TA98 strain that is meant for detecting the presence of frame-shift mutagens. Each sample was tested in triplicate. The twofold increase in the revertant colonies as compared to negative control is considered as mutagenic (Mortelmans and Zeiger 2000). The ratio and percentage mutagenicity of samples was calculated as compared with negative control.

\section{Plasmid nicking assay}

The effect of water sample on the integrity of supercoiled DNA was determined using the plasmid nicking assay described by Tabrez and Ahmad (2011). In this assay, $p B R 322$ DNA is used as a model to study the impact of pollutants on DNA.

\section{Physicochemical analysis}

Physicochemical, biological and microbiological analysis of water samples collected from different points of wetland as presented in Fig. 1 was conducted according to methods provided by standard methods (APHA 1998). The temperature, $\mathrm{pH}$ and electrical conductivity (EC) were measured in situ, and fixation of DO was carried out immediately after the collection of samples.

\section{Heavy metal analysis}

Heavy metal analysis was conducted in water samples collected from 13 different sites Harike wetland as described in standard methods (APHA 1998). Digestion solution was prepared in 1:3 ratios of $\mathrm{HCl}$ and $\mathrm{HNO}_{3}$, respectively. Samples were digested with digestion solution in fume hood. Control was prepared using distilled water (APHA 1998). The concentration of different heavy metals was measured using AAS (Atomic Absorption Spectrophotometer).

\section{Statistical analysis}

The experimental results of mutagenicity, genotoxicity assays and physicochemical parameters were analyzed using SPSS software (SPSS-16). Data were expressed as mean, standard deviation, range, percentage mutagenicity and percentage genotoxicity. All the comparisons were made with controls.

\section{Results}

\section{Mutagenicity assay}

The results of Ames plate incorporation assay are presented in Table 1. The samples from site 1 and 3 showed mutagenicity level greater than $90 \%$ as compared to negative control. The samples from the sites 7, 8 and 9 showed $85 \%$ percentage mutagenicity, while the remaining 7 samples showed less than $80 \%$ mutagenicity. However, it was found that in general, all the samples showed mutagenicity responses from three- to tenfold greater than negative control, thus representing significant mutagenicity indicating the presence of frame-shift mutagens in the water samples.

\section{Plasmid nicking assay}

The pBR322 supercoiled DNA (form I) upon interaction with free radicals, mutagens or other DNA intercalating agents is converted to either open circular DNA (form II) by damaging of single strand of DNA or to linear DNA (form III) as a result of damage to both the strands of DNA. In some cases, there was formation of smear indicating the fragmentation of DNA molecule (Table 2).

The results showed that water samples collected from sites 1, 2, 3 and 8 of Sutlej river system had greater DNA damaging effect, thus was more polluted in terms of 
Table 1 Mutagenic effect of water samples from different sites of Harike wetland in TA 98 tester strain of Salmonella typhimurium in Ames assay

\begin{tabular}{|c|c|c|c|c|c|}
\hline S. no. & Locations & Mean/ \pm SE & Range & Ratio & $\%$ age mutagenicity \\
\hline 1 & Spontaneous & $25.33+0.88$ & $24-27$ & - & - \\
\hline 2 & Tap water (-ve control) & $36.66+2.03$ & $33-40$ & - & - \\
\hline 3 & NPD (+ve control) & $1420+48$ & $1324-1469$ & 38.7 & 97.42 \\
\hline 4 & Site 1 & $386.67+5.2$ & $378-396$ & 10.5 & 90.5 \\
\hline 5 & Site 2 & $365+4.36$ & $357-372$ & 9.9 & 89.9 \\
\hline 6 & Site 3 & $390+7.4$ & $376-401$ & 10.6 & 90.6 \\
\hline 7 & Site 4 & $173+3.79$ & $167-180$ & 4.7 & 78.8 \\
\hline 8 & Site 5 & $162+8.3$ & $150-178$ & 4.4 & 77.37 \\
\hline 9 & Site 6 & $175.33+4.09$ & $169-183$ & 4.8 & 79.09 \\
\hline 10 & Site 7 & $263.67+4.6$ & $256-272$ & 7.2 & 86.09 \\
\hline 11 & Site 8 & $256+8.18$ & $245-272$ & 6.9 & 85.67 \\
\hline 12 & Site 9 & $259.67+6.38$ & $248-270$ & 7.1 & 85.88 \\
\hline 13 & Site 10 & $137.67+6.94$ & $126-150$ & 3.7 & 73.37 \\
\hline 14 & Site 11 & $148.67+4.81$ & $142-158$ & 4.1 & 75.34 \\
\hline 15 & Site 12 & $147+4.73$ & $138-154$ & 4 & 75.06 \\
\hline 16 & Site 13 & $135.67+8.06$ & $124-151$ & 3.7 & 72.97 \\
\hline
\end{tabular}

Table 2 Genotoxic effect of water samples from different sites of Harike wetland in plasmid nicking assay

\begin{tabular}{llrrrrr}
\hline S. no. & Location & \multicolumn{1}{l}{ Form I } & Form II & Form III & Total & \% DNA damage \\
\hline 1 & Control & $2823.67(79.66)$ & $479.33(13.52)$ & $241.67(6.82)$ & 3544.67 & 20.34 \\
2 & Site 4 & $2488.67(55.67)$ & $1224.33(27.39)$ & $757.67(16.95)$ & 4470.67 & 44.33 \\
3 & Site 5 & $3037.33(65.87)$ & $880(19.08)$ & $693.67(15.04)$ & 4611 & 34.13 \\
4 & Site 6 & $2977.67(46.63)$ & $2093.33(32.78)$ & $1314.33(20.58)$ & 6385.33 & 53.37 \\
5 & Site 1 & $557.67(31.38)$ & $328.67(18.49)$ & $891(50.13)$ & 1777.34 & 68.62 \\
6 & Site 10 & $3318(40.38)$ & $3349(40.75)$ & $1550.33(18.87)$ & 8217.33 & 59.62 \\
7 & Site 2 & $522.3(17.17)$ & $894.67(29.41)$ & $1624.67(53.41)$ & 3041.64 & 82.83 \\
8 & Site 3 & $728.7(11.4)$ & $2460(38.49)$ & $3202(50.10)$ & 6390.7 & 88.59 \\
9 & Control & $3344.67(81.34)$ & $517(12.57)$ & $250.33(6.08)$ & 4112 & 18.66 \\
10 & Site 11 & $2071.33(23.74)$ & $3345(38.33)$ & $3310(37.93)$ & 8726.33 & 76.26 \\
11 & Site 12 & $3318.33(57.27)$ & $771.67(13.31)$ & $1704.67(29.42)$ & 5794.67 & 42.73 \\
12 & Site 13 & $2527(28.3)$ & $3120.67(34.95)$ & $3280.33(36.74)$ & 8928 & 71.69 \\
13 & Site 7 & $386(44.09)$ & $100.67(11.5)$ & $388.67(44.40)$ & 875.34 & 55.9 \\
14 & Site 8 & $647.67(10.24)$ & $2830.33(44.74)$ & $2847.67(45.02)$ & 6325.67 & 89.76 \\
15 & Site 9 & $1998(24.94)$ & $2835.33(35.39)$ & $3178.33(39.67)$ & 8011.66 & 75.06 \\
\hline
\end{tabular}

Within bracket the amount of DNA in \% was shown

genotoxicity, than from sites 4,5 and 6 of Beas river, as supercoiled DNA got affected to different levels, when incubated with water from both rivers separately. The results are further strengthened by the fact that damage to supercoiled DNA by water of river Sutlej is lesser at confluence point of both rivers and Feeders (at site 7, 10, 12 and 13). This indicates the diluting effect once the river converges at the confluence and the damaging agents in water samples from Sutlej got moderated. The density of DNA of different forms (i.e., Form I, II and III) was calculated using Quantity One 1-D Analysis Software. The percentage DNA damage was estimated by comparing the density of DNA in form II and form III with total amount of DNA loaded (Table 2). 


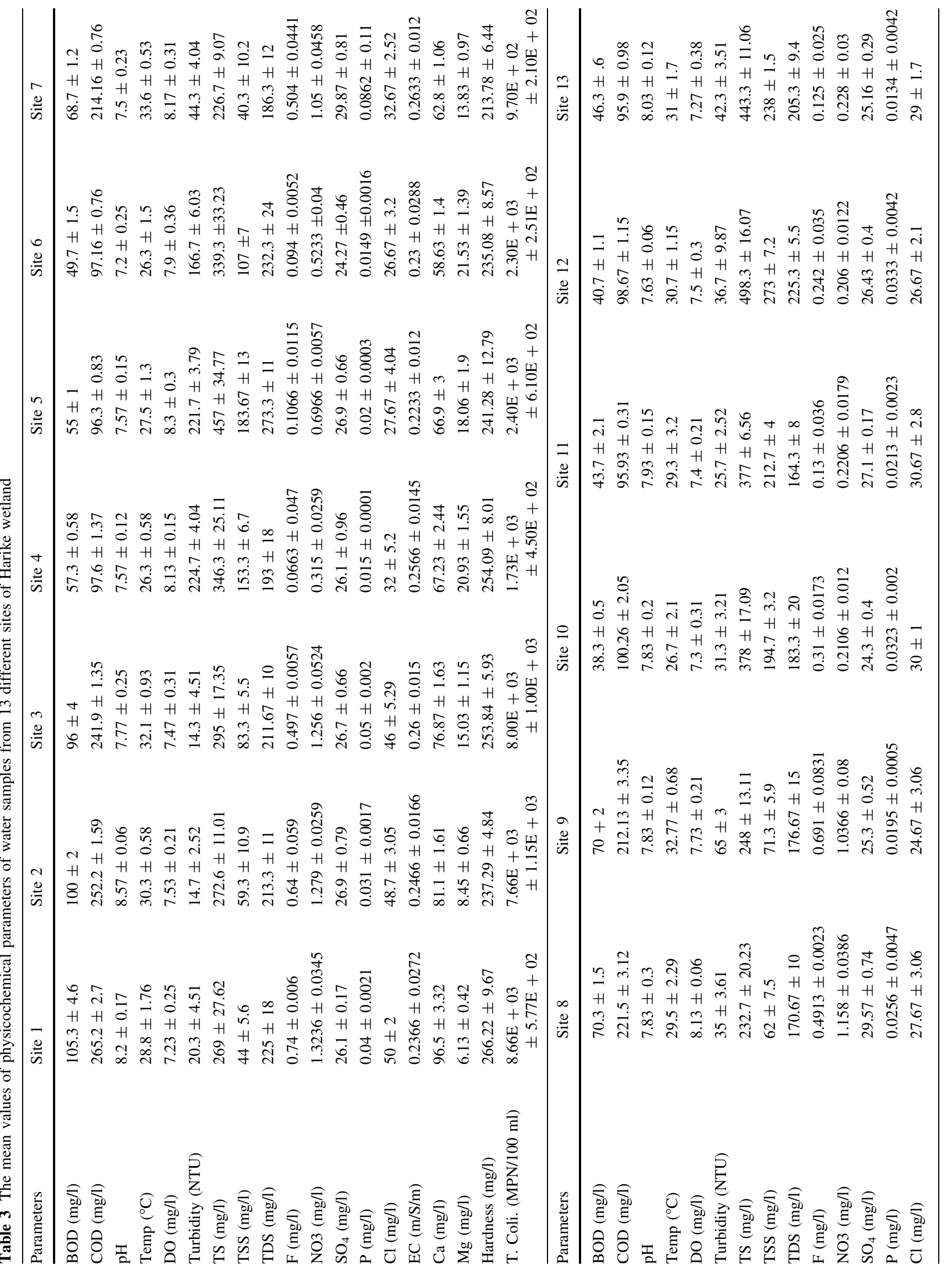




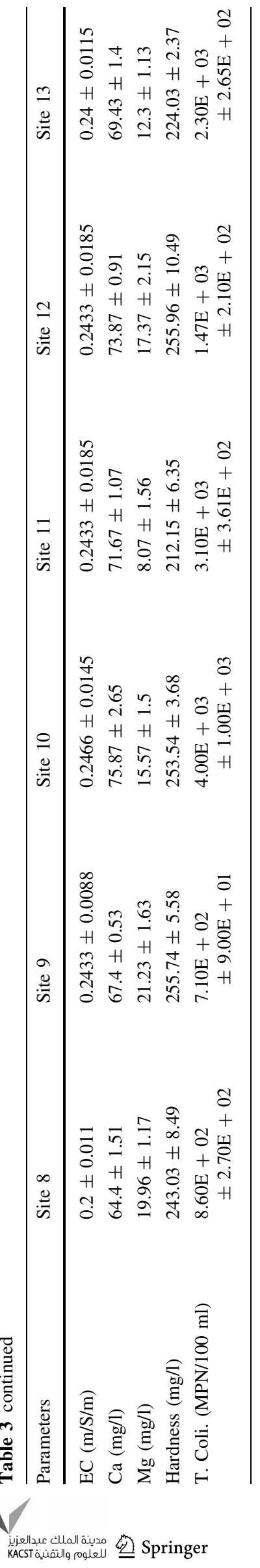

\section{Physicochemical analysis}

The water quality data of Harike wetland system for 19 parameters from 13 different sites are given in Table 3. The values from river Satluj were higher compared to those from river Beas in terms of organic and inorganic pollution (i.e., BOD and COD). The highest value of BOD and COD was from river Satluj at site $1(105,265.2 \mathrm{mg} / \mathrm{l})$ and site 2 (100, $252.2 \mathrm{mg} / \mathrm{l})$, respectively, and lowest from river Beas at site $4(57.3,97.6 \mathrm{mg} / \mathrm{l})$ and site $5(55,96.3 \mathrm{mg} / \mathrm{l})$. The water from river Beas was more turbid than water from river Satluj. The value of turbidity and total suspended solids (TSS) was highest in river Beas at site 4 (224.7 NTU, $153.3 \mathrm{mg} / \mathrm{l})$ and at site 5 (221.7 NTU, $183.6 \mathrm{mg} / \mathrm{l})$, respectively. River Satluj had lowest value of turbidity and total suspended solids at site 1 (20.3 NTU, $44 \mathrm{mg} / \mathrm{l})$ and site 2 (14.7 NTU, $59.3 \mathrm{mg} / \mathrm{l})$. The values of BOD and COD at the confluence point were intermediate, as the water from river Beas dilutes the pollutants in the wetland area carried by river Satluj, i.e., at site 7 (68.7, $214.1 \mathrm{mg} / \mathrm{l})$ and site $9(70,212.3 \mathrm{mg} / \mathrm{l})$. The average DO level in the wetland area was between 7.2 and $8.3 \mathrm{mg} / \mathrm{l}$. The $\mathrm{pH}$ level of water samples was slightly alkaline and varied in between 7.20 and 8.57. There was not much variation in temperature of the samples from all the sites. The other parameters including $\mathrm{F}, \mathrm{P}, \mathrm{SO}_{4}{ }^{2-}$ and $\mathrm{NO}_{3}{ }^{-}$were found within Indian Standard specification for drinking water IS: 10500.

\section{Heavy metal analysis}

The heavy metal analysis data of Harike wetland from different sites are given in Table 4. The highest concentration of heavy metals was found in sites 1, 2, and 3, i.e., samples collected from river Satluj area, while the lowest concentration of heavy metals was found in sites 10, 11, 12 and 13, i.e., samples collected from both the feeders ( Rajasthan and Firozpur feeder, respectively). The concentration of heavy metals in both the reservoirs is less than their respective rivers. The concentration of metals was higher than the drinking water permissible limit provided by WHO.

\section{Discussion}

Pollution of aquatic systems occurs from multiple sources. Wetlands are very vulnerable ecosystems of the world. Even low-level pollution of these ecosystems can cause adverse effects to the ecology (Hildebrandt et al. 2008). There are number of analytical methods that have been used widely for the evaluation of mutagenicity and genotoxicity (Egito et al. 2007; Gupta and Ahmad 2012). In this study, Harike wetland is taken as an area for the analysis. 
Table 4 Heavy metal analysis of water samples collected from different sites of Harike wetland

\begin{tabular}{|c|c|c|c|c|c|c|c|}
\hline S. no. & Sites & Lead (ppm) & Chromium (ppm) & Zinc (ppm) & Iron (ppm) & Copper (ppm) & Mercury (ppm) \\
\hline 1 & Control & 0.0 & $0.00012 \pm 0.001$ & $0.00009 \pm 0.006$ & 0.0 & $0.00013 \pm 0.0003$ & 0.0 \\
\hline 2 & Site 1 & $1.5702 \pm 0.003$ & $0.4706 \pm 0.001$ & $5.9288 \pm 0.0002$ & $9.7671 \pm 0.022$ & $5.2281 \pm 0.002$ & $0.3612 \pm 0.002$ \\
\hline 3 & Site 2 & $2.2002 \pm 0.008$ & $0.4067 \pm 0.001$ & $5.0836 \pm 0.0001$ & $7.3388 \pm 0.001$ & $4.4911 \pm 0.0008$ & $0.0818 \pm 0.001$ \\
\hline 4 & Site 3 & $1.9498 \pm 0.003$ & $0.3288 \pm 0.0005$ & $5.0614 \pm 0.0003$ & $7.0332 \pm 0.001$ & $4.2892 \pm 0.0006$ & $0.0348 \pm 0.006$ \\
\hline 5 & Site 4 & $0.6194 \pm 0.003$ & $0.0642 \pm 0.0005$ & $3.6264 \pm 0.0002$ & $7.0553 \pm 0.002$ & $2.9853 \pm 0.001$ & ND \\
\hline 6 & Site 5 & $0.6215 \pm 0.003$ & $0.0525 \pm 0.0003$ & $3.5092 \pm 0.0003$ & $5.0326 \pm 0.001$ & $3.0248 \pm 0.0006$ & ND \\
\hline 7 & Site 6 & $0.7589 \pm 0.002$ & $0.0812 \pm 0.002$ & $2.3289 \pm 0.0006$ & $5.9726 \pm 0.0003$ & $2.0009 \pm 0.0031$ & ND \\
\hline 8 & Site 7 & $0.2701 \pm 0.0004$ & $0.0165 \pm 0.0092$ & $0.9446 \pm 0.002$ & $3.3289 \pm 0.0006$ & $0.6656 \pm 0.001$ & $0.0097 \pm 0.0214$ \\
\hline 9 & Site 8 & $0.3875 \pm 0.002$ & $0.0482 \pm 0.003$ & $2.0001 \pm 0.002$ & $4.1332 \pm 0.0004$ & $1.7219 \pm 0.002$ & $0.0115 \pm 0.012$ \\
\hline 10 & Site 9 & $0.4367 \pm 0.0003$ & $0.0423 \pm 0.002$ & $1.7456 \pm 0.002$ & $3.9221 \pm 0.0003$ & $1.2113 \pm 0.002$ & $0.0205 \pm 0.003$ \\
\hline 11 & Site 10 & $0.0943 \pm 0.002$ & $0.0098 \pm 0.002$ & $0.6398 \pm 0.003$ & $1.2791 \pm 0.002$ & $0.3914 \pm 0.003$ & ND \\
\hline 12 & Site 11 & $0.06191 \pm 0.002$ & $0.0284 \pm 0.002$ & $0.6477 \pm 0.0004$ & $1.6733 \pm 0.008$ & $0.3289 \pm 0.0006$ & ND \\
\hline 13 & Site 12 & $0.0826 \pm 0.0004$ & $0.0118 \pm 0.004$ & $1.2675 \pm 0.002$ & $2.094 \pm 0.002$ & $0.2371 \pm 0.003$ & ND \\
\hline 14 & Site 13 & $0.1032 \pm 0.002$ & $0.0162 \pm 0.0003$ & $0.8845 \pm 0.002$ & $2.156 \pm 0.002$ & $0.2995 \pm 0.0004$ & ND \\
\hline \multicolumn{2}{|c|}{$\begin{array}{l}\text { Permissible limit in drinking } \\
\text { water by WHO in ppm }\end{array}$} & 0.01 & 0.05 & 3 & 0.3 & 2 & 0.001 \\
\hline
\end{tabular}

Fig. 2 Graph showing the comparison between \% age DNA damaging effect in plasmid nicking assay and \% age mutagenicity in Ames assay

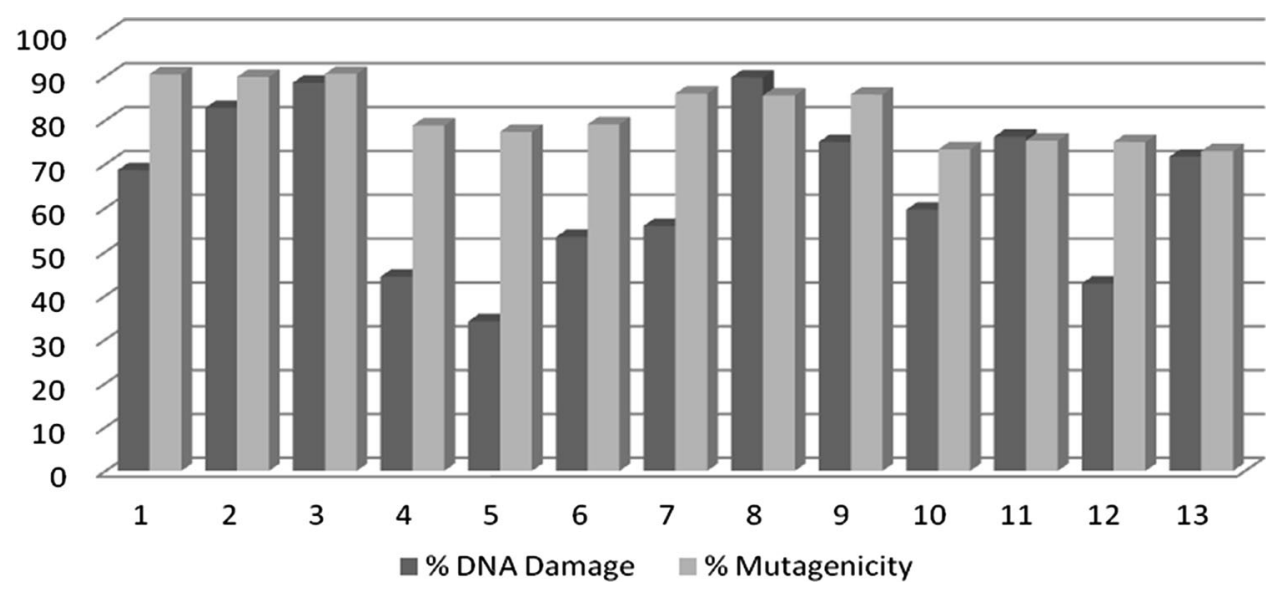

Wetland is surrounded by agricultural field used for cultivation of wheat, rice and other seasonal crops. Over the years, the wetland has been facing a threat from a developing economy with increasing pressure on the resources (Chopra et al. 2001; Jain et al. 2008). As a result, many parts of southern Punjab and Rajasthan are facing a number of health problems. The plants and animals residing in the wetland are also under great pressure of pollutants. To assess mutagenic/genotoxic effect as well as to understand the composition of pollution load of Harike wetland, the present research plan was framed using short-term Ames Salmonella histidine reversion assay and plasmid nicking assay along with determining physicochemical analysis and heavy metal content.

The results of this study suggest that maximum pollution into Harike wetland was brought by river Satluj (site 1 and 2) which was contaminated with toxic chemicals causing mutations in bacterial strains and as well as single and double stranded breaks in plasmid DNA. These assays provide valuable biomarkers for the assessment of poisonous chemicals mixed in our water bodies and their effect on the various components of our ecosystems. (Tabrez and Ahmad 2011; Siddiqui et al. 2011a, b). The risk of mutations caused by these agents inhabiting in the wetlands will pose threat on their existence. (Dearfield et al. 2002). In addition to their direct ingestions, these mutagenic substances can get biomagnified in the food chains and can pose serious health effect on the coming generations (Wu 2005).

Moreover, the bioassays used for estimating genotoxicity and mutagenicity of water sample used in our study works on different principles as in Ames test (with Strain TA 98 of Salmonella typhimurium), the frame-shift mutagens are detected, while plasmid nicking assay (using supercoiled $p B R 322$ DNA) represents the breakage of supercoiled DNA into single and double strand DNA. 
These two systems have different sensitivity level towards contaminants. In this analysis, similar trend has been found in both the assays. The water samples with maximum revertant colonies, i.e., having high percentage level of mutagenicity also cause maximum genotoxicity (Fig. 2). The results of the two assays support each other except for site 4 , site 5 and site 12 that showed high mutagenicity level but low genotoxicity. A critical analysis of results showed that the mutagenic effect of water samples from the different sites was higher than their genotoxic effect except for site 8 and 11, which showed slightly higher values of genotoxicity as compared to mutagenicity.

Physicochemical analysis is widely used as a measure of pollution load in wastewater and natural waters. The level of BOD, COD and TDS was higher at the sites mainly containing the water from river Satluj. The level of turbidity and TSS was higher at the sites that contain water from river Beas which mainly includes the soil particles, which may be due to erosion occurring at the upstream Beas and run-off from the adjacent agriculture fields (Fig. 1). The high level of organic pollution (BOD and $\mathrm{COD})$ and nutrients $\left(\mathrm{NO}_{3}, \mathrm{SO}_{4}\right.$ and $\left.\mathrm{P}\right)$ is the reason for excessive growth of water hyacinth. Heavy metal analysis also showed that maximum toxic components in the wetland are brought in by river Satluj (site 1 and 2). The results of genotoxicity and mutagenicity compared with physicochemical parameters and heavy metal analysis were found to be correlated with each other as the sites showing higher level of pollution and maximum number and concentrations of heavy metals are also causing high mutagenicity and genotoxicity (site 1 and site 2).

The results of mutagenicity, genotoxicity, physicochemical and heavy metal analysis suggest that the water present in the Harike wetland is contaminated with different types of organic pollutants and toxic contaminants that may be causing the mutations and DNA damage. There is also the possibility of presence of other organic and inorganic pollutants in water samples yet to be identified.

\section{Conclusion}

Wetlands rank among the most productive and sensitive ecosystems. They provide habitat to many rare, endangered species and are very important for human population. Thus, adverse effect of pollution on these ecosystems is attracting attention in recent years. In the present study, it has been found that water samples collected from Harike wetland are contaminated with different toxic pollutants. The results of mutagenic/genotoxic analysis showed that pollutants present in wetland are capable of causing mutations and DNA damage in bacterial strain and plasmid DNA.
Physicochemical parameters and heavy metal analysis quantify different organic and inorganic pollutants and identify the toxic components, respectively.

Acknowledgments The authors gratefully acknowledge the research facilities provided by Guru Nanak Dev University (GNDU) Amritsar, Punjab, under UPE, CPEPA (UGC) and financial assistance from the Department of Science and Technology (DST), New Delhi under INSPIRE Program.

Open Access This article is distributed under the terms of the Creative Commons Attribution 4.0 International License (http:// creativecommons.org/licenses/by/4.0/), which permits unrestricted use, distribution, and reproduction in any medium, provided you give appropriate credit to the original author(s) and the source, provide a link to the Creative Commons license, and indicate if changes were made.

\section{References}

Alam ZM, Ahmad S, Malik A, Ahmad M (2009) Genotoxicity and mutagenicity potential of agriculture soil irrigated with tannery effluents at Jajmau (Kanpur), India. Arch Environ Contam Toxicol 57(3):463-476

Alam ZM, Ahmad S, Malik A, Ahmad M (2010) Mutagenicity and genotoxicity of tannery effluents used for irrigation at Kanpur, India. Ecotoxicol Environ Saf 73(7):1620-1628

Aleem A, Malik A (2003) Genotoxicity of water extracts from the river Yamuna and Mathura India. Environ Toxicol 18:69-77

Ames BN (1984) The detection of environmental mutagens and potential carcinogens. Cancer 53:2034-2040

Anonymous. The list of wetlands of international importance. Retrieved from Convention on Wetlands (Ramsar, Iran, 1971). http://www.ramsar.org/pdf/sitelist.pdf. Accessed 1 Aug 2008

APHA (1998) Standard methods for the examination of water and wastewater, 20th edn. APHA, Washington, DC

Chopra R, Verma VK, Sharma PK (2001) Mapping, monitoring and conservation of Harike wetland ecosystem, Punjab, India through remote sensing. Int J Remote Sens 22:89-98

Claxton LD, Houk VS, Hughes TJ (1998) Genotoxicity of industrial wastes and effluents. Mutat Res 410:237-243

Dearfield KL, Cimino MC, McCarrill NE, Mauer I, Valcovic LR (2002) Genotoxicity risk assessment: a proposed classification strategy. Mutat Res 521:121-135

Dhillon SS, Kaur H, Bath KS, Mander G (1996) Aquatic animal diversity and its conservation at Harike wetland. Environ Ecol 14(3):619-623

Egito LCM, Medeiros MDG, Medeiros SRBD, Agnez-Lima LF (2007) Cytotoxicity and genotoxicity potential of surface water from Pitimbu river, northeastern/RN Brazil. Genet Mol Biol 30(2):435-441

Gupta AK, Ahmad M (2012) Assessment of cytotoxic and genotoxic potential of refinery waste effluent using plant, animal and bacterial systems. J Hazard Mat 201-202:92-99

Hildebrandt A, Guillamon M, Lacorte S, Tauler R, Barceló D (2008) Impact of pesticide used in agriculture and vineyards to surface and groundwater quality (North Spain). Water Res 42:3315-3326

Houk VS (1992) The genotoxicity of industrial wastes and effluents: a review. Mutat Res 277:91-138

Hubert FV, Moisan KH, Munschy C, Tronczynski J (2012) Mutagenicity and genotoxicity of suspended particulate matter in the Seine river estuary. Mutat Res 741:7-12 
Jain KS, Sarkar A, Garg V (2008) Impact of declining trend of flow on Harike wetland. Water Res Manag 22:409-421

Kaur H, Dhillon SS, Bath KS, Mander G (1999) Physico-chemical characteristics of water of Buddha Nallah. Indian J Environ Prot $3(1): 27-30$

Ladhar SS (2002) Status of ecological health of wetlands in Punjab, India. Aquat Ecosyst Health 5:457-465

Mabwoga SO, Chawla A, Thukral AK (2010) Assessment of water quality parameters of the Harike wetland in India, a Ramsar site, using IRS LISS IV satellite data. Environ Monit Assess 170:117-128

Maron DM, Ames BN (1983) Revised method for the Salmonella mutagenicity assay. Mutat Res 113:173-215

Mathur N, Bhatnagar P, Nagar P, Bijarnai MK (2005) Mutagenicity assessment of effluents from textile/dye industries of Sanganer, Jaipur (India): a case study. Ecotoxicol Environ Saf 61:106-113

Mortelmans K, Zeiger E (2000) The Ames Salmonella/microsome mutagenicity assay. Mutat Res 455:29-60

Ohe T, Watanabe T, Wakabayashi K (2004) Mutagens in surface water: a review. Mutat Res 567:109-149

Ramsar Convention Secretariat (2006) The Ramsar Convention manual: a guide to the convention on wetlands (Ramsar, Iran, 1971), 4th edn. Switzerland, Gland

Siddiqui AH, Ahmad M (2003) The Salmonella mutagenicity of industrial, surface and ground water samples of Aligarh region of India. Mutat Res 541:31-52
Siddiqui AH, Tabrez S, Ahmad M (2011a) Validation of plant based bioassays for toxicity testing of Indian waters. Environ Monit Assess 179(1-4):241-253

Siddiqui AH, Tabrez S, Ahmad M (2011b) Short term in vitro and in vivo genotoxicity testing system for some water bodies of northern India. Environ Monit Assess 180(1-4):87-95

Simeonov V, Stratis JA, Samara C, Zachariadis G, Voutsa D, Anthemidis A, Sofoniou M, Kouimtzis Th (2003) Assessment of surface water quality Northern Greece. Water Res 37:4119-4124

Singh KP, Malik A, Sinha S (2005) Water quality assessment and apportionment of pollution sources of Gomti river (India) using multivariate techniques-a case study. Anal Chim Acta 538:355-374

Tabrez S, Ahmad M (2011) Oxidative stress-mediated genotoxicity of wastewaters collected from two different stations in northern India. Mutat Res 726:15-20

Vargas VM, Guidobono RR, Jordao C, Henriques JA (1995) Use of two short term tests to evaluate the genotoxicity of river water treated with different concentration and extraction procedures. Mutat Res 34:331-352

White PA, Rasmussen JB (1998) The genotoxic hazards of domestic wastes in surface waters. Mutat Res 410:223-236

Wu JY (2005) Assessing surface water quality of the Yangtze Esturay with genotoxicity data. Mar Pollut Bull 50(12):1661-1667 